Heid Leganger-Krogstad

\title{
Møtet mellom fag og politikk i en læreplanprosess, eksemplifisert ved KRL
}

\section{Sammendrag}

Artikkelen vil drøfte møtet mellom fag og politikk $i$ en lcereplanprosess eksemplifisert med grunnskolefaget KRL. Det er scrlig forholdet mellom ideologisk og formell lcereplan som er i fokus. Av flere grunner var de politiske føringene på lcereplanprosessen når det gjaldt KRL-faget innenfor Kunnskapsløftet ekstra tydelige. For det første fikk planen en pilotfunksjon i reformen fordi den ble innført et år før de øvrige planene, og dessuten fikk planen en scrlig politisk interesse som følge av FNs menneskerettsdomstols uttalelse om KRL-faget i 2004 mens lcereplanarbeidet var i gang. Den prosess planen var gjennom, har fornyet aktualitet etter EMD-dommen i juni 2007. Artikkelen drøfter hvordan juridiske og pedagogiske betraktningsmåter kan komme i konflikt knyttet til fagprofil, fagets formål og fritaksbestemmelsene $i$ skolen. Artikkelen drøfter også føringene fra Kunnskapsløftet knyttet til ferdigheter og drøfter grunnferdighetenes funksjon som mål eller midler og hvilke ferdigheter som er relevante i KRL og hvorfor.

\section{Innledning}

KRL-planen innledet Kunnskapsløftet ved at den ble implementert i grunnskolen høsten 2005, et år forut for alle de andre planene. Oppmerksomheten rundt endringer i skolens religionsundervisning er stor både fra politikere, foreldre og samfunnet til vanlig, men rundt denne revisjonen var det en intensivert politisk interesse. Det hadde to årsaker: For det første fikk faget Kristendoms-, religions- og livssynskunnskap en slags pilotrolle i reformen. Fagplanen fikk derfor en særlig grundig gjennomgang av politisk og faglig ledelse i departementet for å sikre at faget fikk en utforming som var tydelig i overensstemmelse med Kunnskapsløftets intensjoner. For det andre fikk hele faget fornyet politisk interesse etter uttalelsen av 3. november 2004 fra FNs menneskerettskomite i Genève (FNs menneskerettskomite, 2004). Den kom rett i fanget på læreplangruppa, etter at førsteutkastet var offentliggjort, og nødvendiggjorde direkte drøftinger med departement/regjering og omskrivinger av planen i den hensikt å besvare utfordringene fra FN.

Intensjonen med artikkelen er å drøfte deler av denne læreplanprosessen 
med fokus på forholdet mellom elementer av den ideologiske læreplanen og den formelle læreplanen, selve læreplanteksten. Mitt kjennskap til disse prosesser bygger på medlemskap i den nasjonale læreplangruppa for grunnskolefaget KRL (Skolenettet, 2004), altså i arbeidet med første og andre utkast av planen, og deltakelse som fagperson i det oppfølgende arbeidet med å revidere planutkastet i lys av høringene på oppdrag fra Utdanningsdirektoratet og i ferdigstillelsen av læreplanen i samvirke med departement/regjering. Planen gjennomgikk etterskuddsvis en politisk sluttøring uten innsyn fra personer fra læreplangruppa. Fag i tittelen refererer til KRL-faglig og KRL-didaktisk tenkning. Utdannings- og forskningsdepartementet, som vi forholdt oss til, er selvsagt et fagdepartement og gjør således både faglige og politiske vurderinger på et overordnet plan, men uten den fagkunnskap som fagplangruppa var utpekt for å kunne dekke. Møtet mellom fag og politikk refererer til møtet mellom fagplangruppe og fagpersoner på den ene siden, og Utdanningsdirektorat, departement og regjering på den andre. Jeg ønsker å se kritisk på dette møtet.

Analysen vil være todelt:

\section{Diskusjon i forlengelse av FN-uttalelsen}

En kortfattet gjennomgang av tre tema som kom opp til faglig og politisk drøfting i kjølvannet av FN-uttalelsen: fagprofil, fagets formål $i$ opplceringsloven og reglene om religiøst begrunnet fritak. Drøftingen dreier seg blant annet om konflikt mellom juridisk og pedagogisk språkbruk. Denne drøftingen har fornyet relevans ut fra dommen i Den europeiske menneskerettsdomstolen (EMD) i Strasbourg fra 29. juni 2007 (EuropeanCourt of Human Rights, 2007) som ifølge Rundskriv F 15-07 fra Kunnskapsdepartementet gjør atter en ny planrevisjon nødvendig med iverksettelse 2008/2009.

\section{Diskusjon i forlengelse av Kunnskapsløftet}

En mer grundig gjennomgang av integreringen av de fem basisferdighetene $i$ faget som eksempel på politiske føringer fra Kunnskapsløftet. Drøftingen vil gjøres ut fra Wolfgang Klafkis teori om kategorial dannelse. I tillegg vil jeg bringe fram noe av den indirekte kritikk som ligger i endringer regjeringen Stoltenberg foretok i Prinsipper for opplæringen i Læreplan for Kunnskapsløftet (LK06) før iverksettelsen høsten 2006.

Som deltaker i planarbeidet er det nærliggende å være forsvarer av sluttresultatet. Det er da også tilfelle for store deler av planen, men her er valgt ut nettopp de temaene der vi som KRL-kyndige pedagoger måtte 
argumentere tungt for våre synspunkter, hadde vansker med å få gjennomslag, inngikk kompromiss eller ble overstyrt. Da er det viktig å understreke at læreplangruppa, under trygg ledelse av høgskolelektor Dag Ottar Reiten, var ganske samstemte i hele prosessen. Den faglige drakampen mellom religionsvitenskapelige og mer kristendomsfaglige interesser som er relativt vanlig (Østberg, 1998), ble unngått både fordi vi hadde en relativt likeartet oppfatning av skolefagets hensikt, og fordi lederens doble fagkompetanse, både innen kristendomsfag og religionsvitenskap var en stor hjelp. Det var heller ikke slik at praktikerne i skolen argumenterte annerledes enn lærerutdannerne. Et kritisk blikk på fagplanarbeidet fra en som selv var deltaker, forenkles av det faktum at Kunnskapsløftet la opp til en åpen læreplanprosess som omfattet dialog med andre faggrupper, dialog med lærere, publisering av førsteutkast, innspill til dette og utarbeidelse av et andreutkast som ble gjenstand for en omfattende åpen høringsprosess. Dette har gjort det mulig for mange parter å ha innsyn i læreplanprosessen. Læreplangruppa ble oppfordret til å gå åpent ut og gi andre innsyn i prosessen. Vi hadde møter med ekspertgruppene for hver av de fem ferdighetene, men vårt mandat var klart: Å levere en faglig og pedagogisk sett god fagplan vurdert ut fra et KRL-faglig ståsted. Hensyntaken til overordnede politiske føringer var selvsagt nødvendig, samtidig som vi ble oppfordret av Utdanningsdirektoratet til å klargjøre og fastholde vår faglige argumentasjon. Læreplangruppen avsluttet sitt felles arbeid med å avgi andreutkastet. Det var bare noen fra gruppen som fulgte prosessen videre. I siste fase er det et politisk arbeid som foregår ved at regjeringen i samråd med stortingsgruppen legger siste hånd på verket før fastsettelsen av planene. Prosessen denne gang var så omfattende at den førte til to endringer i opplæringsloven, i $\S \quad 2-4$ og en ny $\S \quad 2-3$, og omfattet således Stortingsbehandling (Utdanningsdirektoratet, 2005,51-53).

Denne analysen konsentrerer seg om noen områder av fagplanarbeidet der de politiske føringene og avgjørelsene og de faglige vurderinger kom i konflikt med hverandre. For en som har deltatt i prosessen, er det mulig til en viss grad å sondre mellom steder der KRL-faglige vurderinger har fått telle mest, og der det er tatt avgjørelser på politisk nivå i den endelige teksten. Et mer overordnet kritisk blikk kommer i en annen sammenheng, da jeg arbeider med en artikkel der kompetansebegrepet i Kunnskapsløftet analyseres ut fra nyere teoriutvikling innenfor OECD i kjølvannet av PISAundersøkelsene der de ser kritisk på egen virksomhet.

Kritisk blikk på egen deltakelse forenkles av at en har innsyn i at enhver læreplantekst er et kompromiss-dokument, og av avstand i tid. Videre konstaterer jeg at tekstene synes å ha kortere og kortere levetid, og jeg har innsyn i at en læreplan er langt mer enn den formelle teksten. Den praktiserte 
læreplanen lever sitt eget liv i klasserommet. Det viktigste skjer kanskje i form av oppfattet og praktisert læreplan og i relasjonen mellom læreplanens ulike ansikter etter John Goodlads teori (Goodlad, 1979). Praktisert læreplan i klasserommet er kanskje mer konstant enn både den ideologiske og den formelle læreplanen. Artikkelens hovedinteresse er å analysere relasjonen mellom ideologisk og formell læreplan. Kritisk distanse skaffes også til veie ved å ta i bruk teoretiske briller.

\section{Diskusjonen i forlengelse av FN-uttalelsen \\ Fagprofil}

I sammenheng med FN-uttalelsen ble flere tema aktualisert enn de vi her skal se noe nærmere på. KRL-boka 2005 har en egen del der KRL-fagets historie og aktuelle dokumenter brettes ut (s. 45-54). Denne delen innholder sammendrag av uttalelsen fra FN om brudd på artikkel 18 i FNkonvensjonen om sivile og politiske rettigheter, og regjeringens oppfølging forut for planens iverksettelse høsten 2005. Et av diskusjonsemnene i forhold til FN-uttalelsen var hvorvidt KRL-faget var tilstrekkelig nøytralt og objektivt. Uttalelsen fra FN slår fast at det ikke er noe prinsipielt i veien for å ha religionsundervisning $\mathrm{i}$ en offentlig skole, så sant den ikke bare er undervisning til en religion, men er objektiv og nøytral. Juristene i departement/regjering ønsket å sikre dette ved å inkludere de to begrepene i selve læreplanteksten og kreve at undervisningen som sådan skulle være nøytral og objektiv. Her opplevde vi som pedagoger en klar kollisjon mellom to former for språk, et juridisk og et pedagogisk. Nøytral og objektiv er nok meningsfulle juridiske termer, men som pedagogiske termer påminte de oss om den tilbakelagte debatten om pedagogisk nøytralitet på 1970-tallet. Fagplangruppa argumenterte for at pedagogisk virksomhet i seg selv er en verdibestemt aktivitet med bestemte mål og intensjoner. Fagets intensjon er både å stimulere "til allsidig dannelse, til personlig utvikling og til bevissthet om ens egen identitet” (Utdanningsdirektoratet, 2005, 9). Fagets nøytralitet og objektivitet er heller et spørsmål om fagmodell, argumenterte vi. KRL er et fag der staten er ansvarlig for fagplanen, med trossamfunnene som høringsinstanser. Læremidlene lages av forlagene uten at trossamfunnene har noen innflytelse. Lærerutdanningen er i hovedsak statlig. Lærerne i faget er profesjonelt forpliktet på fagets verdiplattform, men deres personlige syn har liten betydning for faget, og lærerne kan være medlemmer av hvilket som helst religionssamfunn. Disse ordningene borger for at faget er et ordinært skolefag på linje med andre, og statens innflytelse går lenger enn i de fleste andre europeiske land (Kuyk, Jensen, Lankshear, Manna, \& Schreiner, 2007). Faget tilrettelegger for støtte til elevens religiøse og livssynsmessige bakgrunn og inviterer til dialog. 
Norsk skole har definitivt forlatt sin lange tradisjon med konfesjonell kristendomsundervisning - slik det fungerte også ut fra Mønsterplanen av 1987. Den gang tilhørte kunnskap om religioner o-fag/samfunnsfag. Og innenfor kristendomsfaget fantes et relativt lite delemne som het Andre religioner og livssyn, der kristendommens møte med de store verdensreligionene og livssyn var tema. En skulle se på både likheter og forskjeller ut fra en kristendomsfaglig synsvinkel (KUF, 1987, 114). Faget opererte med et flertalls-vi basert på et evangelisk-luthersk syn, et vi som ble tatt for gitt siden det var full fritaksrett i faget. Foreldrene hadde et alternativt fag i livssynskunnskap. KRL-faget fra 1997 har en helt annerledes grunnprofil for å kunne samle alle elevene, en profil med en likeverdig kvalitativ behandling av alle religionene og livssynene, med basis i perspektivpluralisme og integrerende sosialisering (Engen, 1997; Gravem, 2004). Dette kommer til syne ved at et referansepunkt for presentasjonen alltid er nødvendig i læremidlene og i undervisningen for å fortelle ut fra hvilket perspektiv en opererer: Innen Islam ..., innenfor buddhisme ..., de fleste kristne i Norge ..., mange human-etikere argumenterer for ... osv.. Det finnes ikke et "vi" som ser på noen "andre", men kun ett felles vi som utgjør hele klassefellesskapet - et fellesskap bestående av likeverdige medlemmer.

Slik argumenterte vi for at nøytral og objektiv kunne være relevante benevnelser på selve fagkonseptet Kristendoms-, religions- og livssynskunnskap. Fagets profil er i planen fastslått å skulle være et ordinært skolefag, et allmenndannende fag med møteplass for elever med ulik bakgrunn. ”Undervisningen skal gi kunnskap og forståelse, ikke opplæring til en bestemt religion eller et bestemt livssyn. I undervisningen skal likeverdige prinsipper legges til grunn.” Hver religion skal presenteres ut fra sin egenart og " $i$ undervisningen skal det ikke være forkynnelse eller religionsutøvelse” (Utdanningsdirektoratet, 2005, 9). Likeverdighet mellom religionene er i læreplanteksten søkt klargjort gjennom å nevne alle de store religionene ved navn innen hovedområdet Jødedom, islam, hinduisme, buddhisme og livssyn, slik at hver enkelt av dem framstår med sin egenart, og ved å ha gjennomgående likelydende kompetansemål knyttet til alle religioner og livssyn der det er forenlig med selvforståelsen i hver enkelt religion eller livssyn. Dette er synliggjort ved lik verbbruk på tvers av religioner. Likelydende kompetansemål er gitt for å tilrettelegge for kvalitativ likebehandling og mulighet for større grad av sammenlikning. I forhold til KRL-planen fra 2002 er ytterligere to presiseringer tatt inn. Først tilføyelsen om at det i undervisningen ikke skal være religionsutøvelse (Utdanningsdirektoratet, 2005, 9). Dernest en varsomhetsregel: "Det må utøves varsomhet ved valg av arbeidsmåter. Spesielt gjelder det arbeidsmåter som foresatte og elever ut fra egen religion eller eget livssyn kan oppleve 
som utøvelse av annen religion eller annet livssyn.” Skolen plikter dessuten å følge opp fritak med tilpasset opplæring (Utdanningsdirektoratet, 2005, 10).

\section{Fagets formål}

KRL-fagets formål forekommer i lovtekst, og endringer i faget har derfor ofte juridiske implikasjoner som er mer omfattende enn i andre fag. FNs kritikk av KRL-faget var nær knyttet til en passus i den gamle lovteksten der det ble henvist spesifikt til formålet for skolen. FN leste ut av denne henvisningen at kristendommen i KRL skulle behandles kvalitativt forskjellig fra de andre religionene. I prosessen i forhold til FN hadde en nok søkt å få fram hvordan formålet i praksis blir fortolket og praktisert i norsk skole, i hovedsak som en etisk og delvis som en kulturell bestemmelse og ikke som et misjonsprosjekt, men en har ikke nådd fram med dette. Fra politisk hold ble det derfor klart at fagets formål måtte endres. Den tidligere lovteksten hadde i innledningen en direkte henvisning til formålet for norsk skole, og dette ble av FN oppfattet som at faget tilla kristendommen en særskilt status i skolen. Denne henvisningen ble i den nye § 2-4 tatt vekk, og det var det stor enighet om. En nyformulerte imidlertid også formålet med faget:

§ 2-4. Undervisninga i faget kristendoms-, religions- og livssynskunnskap Undervisninga i kristendoms-, religions- og livssynskunnskap skal

- gi grundig kjennskap til Bibelen og kristendommen som kulturarv

- gi grundig kjennskap til evangelisk-luthersk kristendomsforståing og ulike kristne kyrkjesamfunn

- gi kjennskap til andre verdsreligionar og livssyn

- gi kjennskap til etiske og filosofiske emne

- fremje forståing og respekt for kristne og humanistiske verdiar

- fremje forståing, respekt og evne til dialog mellom menneske med ulik oppfatning av trudoms- og livssynsspørsmål.

Kristendoms-, religions- og livssynskunnskap er eit ordinært skolefag som normalt skal samle alle elevar. Undervisninga i faget skal ikkje vere forkynnande.

Den som skal undervise i kristendoms-, religions- og livssynskunnskap, skal presentere kristendommen, dei ulike verdsreligionar og livssyn ut frå deira eigenart. Dei same pedagogiske prinsippa skal leggjast til grunn for undervisninga i dei ulike emna. [I kraft 17 juni 2005]

Denne endringen foregikk på politisk nivå uten at medlemmer av fagplangruppa var involvert, og det er i ettertid ikke vanskelig å se hvorfor også denne formålsteksten har skapt vansker i forhold til EMD. I Opplæringslovens $\S 2-4$ brukes "grundig kjennskap til” to ganger om kristendommen, samtidig som det videre lyder: "kjennskap til andre verdensreligioner og livssyn” (Utdanningsdirektoratet, 2005, 28). Slik dette 
er formulert, kan det synes som faget skal gi kristendommen en kvalitativt annen behandling enn det øvrige stoffet, hvilket ikke stemmer overens med planen for øvrig. Beklagelig er det videre at lovteksten bruker begrepet "andre verdensreligioner", en benevnelse fagplangruppa ellers omhyggelig unngikk på grunn av den vanskelige benevnelsen "andre". Andre del av lovteksten er mer i overensstemmelse med fagplangruppas intensjoner. Denne lovteksten blir naturlig nok referert i formålskapittelet, selv om det var deler av teksten fagplangruppa ikke syntes traff faget særlig godt. Lovteksten bruker benevnelsen "evangelisk-luthersk kristendomsforståelse" som om den er tydelig presisert i læreplanen, men det er den ikke i systematisert forstand. Den er der som kulturelt faktum og som erfaringsbakgrunn for majoriteten av elevene i landet, altså ut fra en stedegenhetstenkning, men ikke som systematisk trosoppfatning, som konfesjon. Den norske kirke er f. eks. ikke eksplisitt nevnt i planen, selv om de fleste ville finne det naturlig. Dette har altså ikke helt uventet skapt nye problemer.

Plangruppa så at FN-uttalelsen påpeker skolens formålsbestemmelse som det egentlige problemet i forhold til å forstå fagets profil. Enklest ville det derfor vært å endre formålet for skolen i forbindelse med planrevisjonen i 2005, men det var det ikke politisk vilje til. Vi vet alle at politiske prosesser går etappevis og ofte stykkevis og delt. Slik kan ulike formelle bestemmelser komme i utakt med hverandre og den oppfattede læreplanen justerer dette. Dette gjelder i særlig grad fortolkning av lovtekster. Alle lovtekster har en sedvanefortolkning, og skolens formålsparagraf er en slik der benevnelsen kristen i sedvanlig fortolkning betyr kristen i etisk og kulturell mening og ikke i religiøs mening. Skolens formål er altså ikke å gjøre elevene kristne i religiøs forstand. Læreplangruppa argumenterte derfor for en endring av formålsbestemmelsen i pakt med sedvanefortolkning og for å imøtekomme en plural virkelighet, framfor å gjøre store endringer i faget. Vi ser av dommen fra EMD at argumentene gjentar seg. Det knappe flertallet i EMD hevder at formålet overstyrer det som står av bestemmelser om faget i fagplanen. Det pågående arbeid med endring av formålet for norsk skole, vil etter mitt syn løse denne floken.

\section{Fritak}

I ly av fagplanarbeidet ble det imidlertid samtidig foretatt en opprydding i Opplæringsloven. Religiøst begrunnet fritak i skolen omfatter langt mer enn KRL, selv om det så langt i hovedsak har vært drøftet i den sammenhengen. Den tidligere loven tok bare hensyn til fritak innenfor rammen av KRL, og det ble utarbeidet skjemaer for å tilrettelegge for dette fritaket (UFD/Læringssenteret, 2002). Men religiøst begrunnet fritak i skolens 
virksomhet er langt mer enn en sak for KRL. Religion og skole i pluralistiske samfunn skaper utfordringer uavhengig av skolesystem og modell for religionsundervisning og gjør bevissthet om og håndtering av disse tema nødvendig. Det har de siste årene foregått et faglig drøftingsarbeid innenfor Europarådet, en oppfølging av Soria Moria-konferansen i Europarådets regi i Oslo i juni 2004 om The religious dimension of intercultural education. Det nye prosjektet har gått under benevnelsen Religious Dimension in Education in Pluralist Societies, og jeg har vært norsk deltaker. Resultatet foreligger i boka: Religious diversity and intercultural education: a reference book for schools (Keast, 2007). Drøftingen påpeker behovet for å inkludere den religiøse dimensjon i utdanning i alle stater uavhengig av om en har et eget fag for religionsundervisning, fordi opplæring til demokrati og medborgerskap (citizenship) krever det.

Elever i norsk skole kan ha behov for fritak i svært mange sammenhenger: fri for å kunne feire sine egne høytider, fritak fra elementer i skolens høytidsmarkeringer og tradisjoner, fritak fra overnattingsturer, leirskole, kino, teater, dans, kjønnsblandet svømming og idrettsstevner. Skolens kleskode, meny, helsetjeneste, kriseplan, kunstsamling, sangrepertoar osv må ta høyde for det flerkulturelle samfunnet. Religiøst begrunnet fritak er derfor oftest en sak som angår skolens drift og dermed rektor og ikke KRL-faget og KRL-læreren. Fritak er derfor nå skilt ut i en egen paragraf § 2-3a og heter Fritak fra aktiviteter med mer i opplæringa for å markere at det dreier seg om undervisning generelt:

\section{§ 2-3a. Fritak frå aktivitetar m.m. i opplceringa}

Elevar skal etter skriftleg melding frå foreldra få fritak frå dei delar av undervisninga ved den enkelte skolen som dei ut frå eigen religion eller eige livssyn opplever som utøving av ein annan religion eller tilslutning til eit anna livssyn, eller som dei på same grunnlag opplever som støytande eller krenkjande. Det er ikkje nødvendig å grunngi melding om fritak etter første punktum.

Det kan ikkje krevjast fritak frå opplæring om kunnskapsinnhaldet i dei ulike emna i læreplanen. Dersom skolen på eit slikt grunnlag ikkje godtek ei melding om fritak, må skolen behandle saka etter reglane om enkeltvedtak i forvaltningslova.

Skolen skal ved melding om fritak sjå til at fritaket blir gjennomført, og leggje til rette for tilpassa opplæring innanfor læreplanen.

Skoleeigaren skal årleg informere elevane og foreldra til elevar under 15 år om reglane for fritak.

Elevar som har fylt 15 år, gir sjølv skriftleg melding som nemnt i første ledd. [I kraft 17. juni 2005]

Innenfor KRL er det bestemte ting som det må tas hensyn til og som kan utløse behov for fritak. Det kan være knyttet til drama, tegning, sang, opplesning fra religiøse kilder, ekskursjoner eller samarbeidstiltak i nærmiljøet som inkluderer religiøse aktiviteter. I mange tilfeller kan 
oppgavene differensieres for å unngå fritak, men ikke alltid. Denne endringen i fritaksretten tok læreplangruppa initiativ til, og her fikk pedagogisk tenkning innflytelse på en juridisk tekst. Fritaksskjemaene er borte som en følge av denne lovendringen, og det er meningen at de fleste henvendelser fra foreldre om behov for fritak skal rettes til rektor på begynnelsen av skoleåret.

I forlengelse av FN-uttalelsen har jeg diskutert hvordan juridiske og pedagogiske betraktningsmåter kan komme i konflikt. Det er klargjort hvordan lovverk og planverk ofte kommer i utakt og skaper vansker for forståelsen av KRL som fagkonsept særlig utenfor Norge. Det knappe flertallet mot Norge i EMD leser hele faget i lys av et kristent formål i religiøs forstand.

\section{Diskusjon i forlengelse av Kunnskapsløftet - grunnleggende ferdigheter}

Et av de nye grepene i Kunnskapsløftet er satsingen på Grunnleggende ferdigheter i alle fag. KRL fikk som nevnt en viss pilotrolle da det som en følge av FN-uttalelsen ble besluttet å framskynde den nye læreplanen i KRL til høsten 2005. Dette førte til økt politisk oppmerksomhet for å sørge for at planen fikk en utforming som svarte til intensjonene i St.meld 30 (2003/2004) og ble utformet i tråd med dominerende internasjonale skolepolitiske trender innenfor blant annet EU og OECD med fokus på samfunnsnyttige ferdigheter og kompetanse som midler i en kunnskapsbasert økonomi (OECD, 2003, 2005).

Kompetansemålene er formulert på en måte som synliggjør de fem grunnleggende ferdighetene, å kunne uttrykke seg muntlig, lese, regne, uttrykke seg skriftlig og bruke digitale verktøy, og målene i læreplanene har bygget inn en viss taksonomisk utvikling av dem.

Til grunn for utviklingen av ferdigheter ligger fysisk modning, stimulus og trening (Evenshaug \& Hallen, 1977, 34ff). Ferdigheter forutsetter prøving og feiling, skrittvis innføring av tjenlige handlings- eller tenkemønstre, instruksjon, etterligning av gode forbilder og løsninger, praktisering, trening, repetisjon. Overlæring er nødvendig for at ferdigheten blir mer eller mindre automatisert. Når en ferdighet er automatisert, finnes det en viss kapasitet til å utvikle større kyndighet og tilpasningsevne etter ytre omstendigheter og behov.

Læreplanene legger opp til at de grunnleggende ferdighetene skal mestres i økende tempo med større stoffmengder på vanskeligere saksforhold og inkluderer evnen til å analysere, sammenlikne, bedømme og vurdere saksforhold kritisk. Det er etter hvert også ønskelig at elevene tilegner seg et metaperspektiv på egen læring, ved at de oppøver evnen til å språkliggjøre og bevisstgjøre selve ferdighetslæringen og vurdere egen utøvelse. 


\section{Basisferdighetene - mål eller middel?}

De politiske føringene læreplangruppene fikk på ferdighetsfeltet var ikke særlig klargjørende. Selv om det var nedsatt ekspertgrupper innen hver ferdighet, kom resultatene fra disse gruppene såpass seint inn i prosessen at KRL-gruppa opplevde mye famling på dette området. Fagplangruppa ble orientert om arbeidet i alle gruppene, og medlemmer derfra fungerte som ressurspersoner i forhold til læreplangruppa. Den første tiden dominerte en mål-tenkning når det gjaldt ferdighetene, men den ble etter hvert justert på en måte som ga større rom for en middel-tenkning. Vi skal se nærmere på ferdighetene forstått som henholdsvis mål og middel.

\section{Mål}

Med det fokus ferdighetene hadde i første fase av læreplanprosessen og ikke minst det trykk en erfarte på å teste evnen til å lese, skrive og regne, i årene forut for prosessen, kunne en lett få inntrykk av at ferdighetene var det egentlige målet. Er det slik at ferdighetene eller arbeidsmåtene selv er pensum? Ligger vekten på innøving av ferdigheter som er overførbare fra en skolesituasjon til yrkesliv ut fra et pragmatisk nyttehensyn?

Kunnskapsløftets initiativtaker, utdannings- og forskningsminister Kristin Clemet, grunnga behovet for nye læreplaner i en artikkel i Bedre Skole i 2004 slik:

Når kunnskapstilfanget i samfunnet øker, kan ikke grunnopplæringen forventes å dekke alle temaer og fagområder som kan synes aktuelle. På den annen side er det grunn til å øke forventningene til skolen som et sted der vi tilegner oss grunnleggende ferdigheter, kunnskap, arbeidsmåter og læringsvilje.

(Clemet, 2004)

Ferdighetene nevnes altså først og tillegges en viss kompenserende effekt. Argumentasjonen er at mengden kunnskap øker så hurtig at skolen kun kan gi smakebiter, men når det gjelder ferdigheter og arbeidsmåter samt en vilje til å lære, kan en forvente mer av skolen. Vi må spørre: Innebærer dette at den nye læreplanen gir ferdighetene en status som minner om tidligere teorier om formal danning der oppøving av bestemte tenkeevner, konsentrasjonsevne, viljestyrke eller ferdigheter var det egentlige poenget? Inntrykket av formaldanning forsterkes av det faktum at de fem ferdighetene skal gå igjen som basisferdigheter $\mathrm{i}$ alle fag. Kan de grunnleggende ferdighetene være like relevante i alle fag? Det kan lyde som om innholdet i fagene dermed blir underordnet denne evnen til å lære eller å tenke og resonnere. 
Her kan det være på sin plass å minne om en erfaring fra kristendomsfagets tid på 1980-tallet da det ”å lære å lære” ble målet. Studietekniske arbeidsmåter fikk dominere over andre mer faglige relevante arbeidsmåter. Oppgaver knyttet til kjernetekster som Fortellingen om den barmhjertige samaritan, lød som følger: noter fem nøkkelord i teksten, slå opp og skriv ned forklaringer til ordene, bruk atlas og finn hvor mange kilometer det er mellom Jerusalem og Jeriko. Slik overtok formaløvinger, og tiden strakk ikke til å arbeide med tekstens innhold. Studieteknikken ble et mål i seg selv, fordi man skulle lære å lære.

Det er derfor, etter min mening, helt avgjørende at fokus på ferdighetslæring ikke blir tilsvarende enøyd og formalistisk denne gang. Et nylig publisert arbeid fra Høgskolen i Vestfold om norsklæreres arbeid med tekster i andre fag viser at det fortsatt er behov for å diskutere og klargjøre forskjellen på konsentrasjon på ferdigheter og på faginnhold. I tre ulike bidrag i denne publikasjonen drøftes arbeid med KRL-tekster, og alle har fokus på tekst og tekstforståelse, formelle strukturer og vanskelige passasjer i læreboktekster i KRL. Denne arbeidsmåten kan imidlertid ut fra en religionsfaglig betraktingsmåte ikke erstatte et religionsfaglig arbeid med tekstene, men kan fungere som forberedelser (Askeland \& Maagerø, 2007, 23-30 og 55-59). Forfatterne hevder at ferdighetene er særskilt viktige i møte med KRL fordi læreboktekstene i faget er så kompliserte og krevende at dette tar oppmerksomheten vekk fra tekstens innhold. Tekstenes vanskegrad er vurdert ut fra leselighetskriterier. Denne vurderingen av læreboktekster i KRL bekrefter et generelt inntrykk jeg sitter med fra kontakt med lærere i videre- og etterutdanningssammenheng. Det pekes altså ut et behov for enten å forenkle tekstene, eller å gjøre ferdighetsøvelser på KRL-tekster i norskfaget.

Vekten på ferdighetene har også sammenheng med læringsbegrepet som legges til grunn i Kunnskapsløftet gjennom valget av læreplantype, en læreplan bestående av kortfattede læreplaner for fag bestående av kompetansemål. Kompetanse innebærer evne til å ta i bruk det innlærte. Læring i denne planen er kun kunnskap og ferdigheter som er tilegnet på en slik måte at de kan anvendes til å løse bestemte oppgaver. Fokusforflytningen fra undervisning til læring, fra lærerens formidling til elevens læring, fører til større vekt på å tilegne seg ferdigheter for å forbedre læreprosessen. Ferdighetene er viktige for å kunne presentere og demonstrere det tilegnede som et ledd i kravet om å måle og vurdere tilegnelse.

Formaldanning er imidlertid en fare her også ved at drilling i selve presentasjonsformen tar over for fokus på faginnholdet. Nasjonale prøver i lesing, regning og skriving øker selvsagt fokus på mestringen av selve ferdighetene. Det er en klar fare for at prøvene presser fram bruk av de 
samme arbeidsmåtene i alle fag, altså mer likelydende mål i fagene når lokale planer skal lages. Dette vil nok også oppleves som forenklende for praksis for mange lærere. Ferdighetene blir mål.

\section{Middel}

Læreplanen av 2006 er iverksatt for å føre til et Kunnskapsløft. I ovennevnte artikkel av Clemet blir de grunnleggende ferdighetene kalt for redskaper eller basisferdigheter. Betyr det at ferdighetene kun er midler? Ferdighetene er så basale at de skal innarbeides i alle fag, og de skal danne grunnlag og forutsetninger for læring. Som midler blir de vektlagt opp til et visst alderstrinn, men forsømt etter det, siden de kun er å forstå som midler for å nå den egentlige kunnskapen i fagene som skolen skal gi. Tenkes det at faglærerne som kommer inn i skolen på høyere trinn kan overlate til lærerne på de første trinnene å innøve de grunnleggende ferdighetene og selv konsentrere seg om fagstoffet? I så fall forstås ferdighetene som kun en del av prosessen for å lære selve faginnholdet og som lite viktige i seg selv. Det er å besørge tilegnelsen av faginnholdet, det vil si det å gi kunnskap, som forblir skolens oppgave, kan mange hevde. Skolen skal gi innblikk i det klassiske lærestoffet eller lære alle det "viktige" innholdet innen alle grunnleggende fagfelt. Er ferdighetene da uten egenverdi?

\section{Mål og middel}

I arbeidet med læreplanen bidro ekspertgrupper innen de fem grunnleggende ferdighetene med hjelp til å etablere en taksonomisk struktur på ferdighetene som ble integrert i læreplanene, og dette ble også del av den gjennomgang som ble gjort i departementet i siste instans. Det er nettopp behovet for å oppøve økende ferdighetsnivå for å kunne lære mer som er Kunnskapsløftets idé. En trenger leseferdigheter på et annet nivå for å kunne forstå mer av et kunnskapsområde, forstå fagets grunnleggende spørsmål og struktur for å kunne forholde seg kritisk til kunnskapen som presenteres i ulik sammenheng. De fem ferdighetene er altså ikke målet. Målet er ikke formal dannelse alene. Ferdighetene må kobles til faginnholdet. De er heller ikke bare midler, men skal være integrert del av den faglige kompetansen.

Pedagogen Wolfgang Klafkis teori (2001) om ønskelig danning kan komme til nytte her. Han benevner dannelsen som kategorial dannelse, en dobbeltsidig prosess der den formale og materiale danning står i et dialektisk forhold til hverandre. De to synene ovenfor må forenes, ikke bare mål og ikke bare middel. Skolen kan ikke være enten kunnskapsorientert eller aktivitets- eller ferdighetsorientert. Både oppøving av de iboende evner, tenkeevne og viljestyrke på den ene side og kulturinnhold og kunnskapsinnhold på den annen side, er nødvendige for at et menneske skal 
dannes. Kunnskapsinnholdet må ha kategorial karakter for mennesket, slik at det ikke bare lærer om, men lærer av det kunnskapsstrukturene representerer. For å kunne lære å lære trenger man å lære et fagområdes grunnstrukturer i den hensikt å ha en grunnforståelse å kunne plassere ny forståelse innenfor. Utvalg av stoff en fordyper seg i gjennom undervisningen, er derfor særdeles viktig slik han ser det. Stoffet en velger ut, må være egnet til å vise grunnstrukturene i det kulturområdet kunnskapsområdet avspeiler, vise fagets egenart og stå sentralt faglig sett slik at det er egnet til å demonstrere noe som er overførbart til andre deler av virkelighetsområdet. Han benevner denne tenkemåten med det eksemplariske prinsipp. Formal dannelse og material dannelse, er to dialektiske deler av den kategoriale dannelse, hevder Klafki (Klafki, 2001; Myhre, 1978). Slik blir ferdighetene verken bare mål eller bare midler, men ferdigheter og kunnskapsinnhold må utfylle hverandre.

Er det da slik i planen? Det er en viss avstand mellom planen og Klafkis tenkning. Betoningen av de fem ferdighetene i fagplanen innebærer vekt på metoder snarere enn på formal danning i form av dyrking av elevens iboende evner eller krefter slik at de kan utfoldes i personlig vekst, slik Klafki tenker. I KRL-planens tekst overskygger de samfunnsnyttige ferdighetene elevens behov for personlig danning. Reidar Myhre omtaler to typer formale dannelsesteorier hos Klafki ved å kalle dem "evneformalisme og metodeformalisme" og to typer materiale dannelsesteorier "encyklopedisme og klassisisme” (Myhre, 1994, 118). Myhre hevder videre at alle teoriene inneholder delsannheter, det er balansen mellom dem som må opprettholdes. KRL-planen står i fare for å tillegge ferdighetene vekt, mens den overser utviklingen av evnene.

Om vi går tilbake til utgangspunktet for Kunnskapsløftet, til St.meld. 30 (2003/2004) Kultur for læring, synes et begrepspar å være glemt: dannelse og grunnleggende ferdigheter. Vi kan spørre hvor det ble av denne dannelsen i læreplanprosessen. I kapittel 4.2 under overskriften Dannelse og grunnleggende ferdigheter skrives følgende:

Kvalitetsutvalget definerer «basiskompetanse» som en del av en helhetlig kompetanse. Denne basiskompetansen defineres av utvalget som lese- og skriveferdigheter, regneferdigheter og tallforståelse, ferdigheter i engelsk, digital kompetanse, læringsstrategier og motivasjon (innsats og utholdenhet) og sosial kompetanse. Utvalget foreslår at basiskompetanse skal uttrykkes gjennom egne kompetansemål i alle læreplanene for fag og at den skal bestå av elementer som går på tvers av fag, dvs. kunnskaper, ferdigheter og holdninger som ikke er spesifikke for bestemte fag, men som skal være en nøkkel for den enkeltes tilegnelse av ny kunnskap og dannelse av egen identitet. Målet er at alle elever og lærlinger skal opparbeide et nødvendig 
kompetansenivå i de mest sentrale ferdighetene for å kunne ta del i kunnskapssamfunnet. Det skal hjelpe dem i deres personlige utvikling og deres evne til å delta i og utvikle seg i skole, samfunns- og arbeidsliv. (Utdannings- og forskningsdepartementet, 2004)

Her er det altså ikke bare snakk om kun basisferdigheter, men om basiskompetanse. En kompetanse som forener ferdigheter, læringsstrategier, motivasjon og sosial kompetanse. Hvorfor skjedde denne innsnevring fra basiskompetanse til basisferdigheter i Kunnskapsløftet? Vi registrerer at den sosiale kompetansen som nevnes i stortingsmeldingen ikke var særlig mye framme i læreplanprosessen. Fagplangruppa møtte motstand da den gjerne ville vektlegge denne kompetansen. Men Stortingsmeldingen stopper heller ikke her, den omtaler skolens oppgave som både å gi basiskompetanse og allmenndannelse:

Allmenndannelse gir innsikt i det komplekse å være menneske, om relasjonen mellom den enkelte og de andre, samt mellom menneske og samfunn. Skolens bidrag til allmenndannelsen skjer i hovedsak gjennom arbeidet med fagene i skolen. Ved å arbeide med fagene oppøves ferdigheter i lesing, blant annet for at elevene skal få tilgang til det store tilfanget av litteratur som er tilgjengelig, og for å kunne orientere seg $\mathrm{i}$ et stadig mer leseintensivt samfunn. Gjennom fagene blir elevene kjent med sin egen og andre lands kultur og historie.

Dette tyder på at dersom flere av intensjonene i Stortingsmeldingen hadde vært tydeligere føringer i læreplanprosessen, ville vi fått en mindre middelog nytte-orientert plan. Vi ser altså at forarbeidene til Kunnskapsløftet tar høyde for mer kategorial dannelse etter Klafki (2001) enn gjennomføringen av selve reformen.

\section{Relevante ferdigheter i KRL?}

Læreplangruppenes oppdrag var å integrere alle ferdighetene der det var naturlig på fagenes egne premisser, og læreplangruppene ble forespeilet at de kunne legge til noen mer fagspesifikke ferdigheter. Dette ble bare delvis tilfelle av årsaker som klargjøres nedenfor.

Oppgaven bestod i å skulle integrere de fem ferdighetene i arbeidet med faget der disse kunne inngå som en naturlig del av læreprosessen og øke den faglige kompetansen. Tanken er at de grunnleggende ferdighetene skal trenes og utvikles også i KRL-faget der de gjør læringen av faget enklere og bedre. De bør altså ikke få dominere over faginnholdet, men relateres til faginnholdet. Siden faginnholdet i disse planene er angitt i form av kompetansemål, så vil mange av målene samtidig angi et visst forventet ferdighetsnivå.

Det var en tydelig politisk forventning om at alle læreplangruppene skulle 
formulere planene med etterprøvbare og målbare kompetansemål. Fagplangruppa i KRL-faget fant dette kravet dels uforenlig med kravet om at alle læreplanene samtidig skulle være korte og konsise. Stoffutvalget innen ulike kompetanseområder skulle overlates til profesjonene og ikke nevnes ved hjelp av lister av stikkord, men heller ved hjelp av noen mer utvalgte, overordnede kategorier. Bruk av slike overordnede kategorier gjorde planene lite eksakte og tydelige. Vi oppfattet dette som en logisk konflikt. Hvordan kan man måle oppnådd kompetanse når stoffet angis som store stoffområder? KRL-planen er likevel blitt mer detaljrik enn andre fag, blir det hevdet. Dette ble det gitt tillatelse til ut fra den store oppmerksomhet denne planen får fra ulike parter i samfunnet, elever, foreldre, lærere, trossamfunn og livssynssamfunn og myndigheter. Kompetansemålene skulle avspeile en taksonomisk utvikling av basisferdighetene, og denne taksonomien ble utviklet med støtte i veiledningen ekspertgruppene for de ulike ferdighetene ga.

Likevel oppstod flere dilemma. Var taksonomiene faglig relevante for KRL, og hvordan kunne planen angi ferdigheter knyttet til ulike emneområder i faget uten samtidig å foreskrive bestemte arbeidsmåter? Skulle planen gi hjelp til å velge egnede arbeidsmåter til ulike stoffområder, altså vektlegge bredde og kreativitet, eller skulle planen bruke trauste og ganske allmenne formuleringer som ga åpning for et friere valg av arbeidsmåter for den enkelte lærer og ved den enkelte skole?

Planen viser at læreplangruppa valgte de allmenne kategoriene som gir frihet til det lokale leddet. I den aller siste politiske bearbeidelsen av planen ble det valgt ennå flere allment formulerte mål: Forslaget om "lese og tolke" De ti bud under området kristendommen på 7. trinn ble byttet ut med "samtale om". Likeledes ble formuleringen "selv skape estetiske uttrykk knyttet til de ulike religionene" på 4. trinn, erstattet i siste fase av "gjøre bruk av estetiske uttrykk". I hovedemnet Etikk og filosofi på 4. klassetrinn er læreplangruppas forslag "vise respekt og toleranse" blitt erstattet med "samtale om respekt og toleranse".

Resultatet er at verbbruken i kompetansemålene avspeiler en betydelig mindre variasjonsbredde enn den en finner i beskrivelsen av ferdighetene under overskriften Grunnleggende ferdigheter i innledningen til planen. Dette hadde minst to årsaker: En ville for det første søke å hindre at kompetansemålene bidro for sterkt til å låse arbeidsformene som kunne velges. For det andre foregikk planarbeidets sluttføring etter at FN-uttalelsen fra november 2004 forelå, og den førte til en stor grad av forsiktighet i utformingen av kompetansemålene. Alle kompetansemål måtte passe for alle elever uavhengig av deres religionstilhørighet og bakgrunn og kunne derfor ikke kreve demonstrasjon av ferdigheter som bare passet for noen 
elevgrupper. Det ble videre krevd stor forsiktighet i forhold til å angi kompetansemål som forutsetter involvering av elevene i religiøse aktiviteter eller noe de kan oppfatte som religiøse aktiviteter, jfr. § 2-3a om fritak i Opplæringsloven. Dette uttrykker imidlertid klart et pedagogisk dilemma for hvordan en skal kunne forklare et stoffområde uten å engasjere og involvere elevene og anvende pedagogisk interessevekkende metoder. Forskningen til Ingunn Folkestad Breistein og Hege Bjerkestøl Beckmann viser at bruk av sang og musikk er klart svekket i KRL (Breistein \& Beckmann, 2006). Dominerende syn på læring for tiden både innen konstruktivistisk og sosiokulturell teori er at læring forutsetter opplevelse og erfaring, og dette må sies å stå i klar kontrast til mange av de svært forsiktige, i betydningen distanserte, verbene i kompetansemålene. Belegg for dette er at i KRLplanen finner man at begrepet erfaring bare nevnes under den generelle omtalen av skriftlig ferdighet, mens verbet oppleve kun brukes under beskrivelsen av ferdigheten å lese. Begrepene brukes som verb eller substantiv flittigere i andre fagplaner, som kroppsøving, naturfag og kunst og håndverk.

Denne forsiktigheten i kompetansemålene kompenseres i den generelle angivelsen av arbeidsformer i formålskapittelet i faget. Her angis et bredere spekter, og bredden er styrket fra høringsutkastet til endelig læreplan:

Det skal benyttes varierte og engasjerende arbeidsmåter, som skal bidra til å formidle alle sider ved faget. Aktiviteter som fortelling, forming, dramatisering, sang og musikk, samtaler og besøk skal bidra til å engasjere elevene og gi innsikt i ulike religioner og livssyn.

(Utdanningsdirektoratet, 2005, 9)

En stor bredde av arbeidsmåter nevnes, og engasjement og innsikt er understreket. Dette står sammen med formuleringen: ”Det må utøves varsomhet ved valg av arbeidsmåter.” Likeledes er fagets bidrag til personlig utvikling og elevenes identitetsutvikling klargjort gjennom følgende formulering fra formålsavsnittet:

I faget skal det stimuleres til allsidig dannelse, til personlig utvikling og til bevissthet om ens egen identitet.

(Utdanningsdirektoratet, 2005, 9)

Det er også understreket at behovet for nærhet til fagstoffet kombineres med en viss faglig distanse gjennom en annen formulering fra formålsavsnittet:

I undervisningen skal likeverdige pedagogiske prinsipper legges til grunn.

Kristendommen, de ulike verdensreligioner og livssyn skal presenteres ut fra sin egenart. Det innebærer at alle religioner og livssyn skal behandles på en faglig og sakssvarende måte ut fra sitt særpreg. I undervisningen skal nærhet til fagstoffet på religionenes og livssynenes egne premisser kombineres med saklig distanse. I undervisningen skal det ikke være forkynnelse eller 
religionsutøvelse

(Utdanningsdirektoratet, 2005, 9)

Disse tilsynelatende motstridende utsagnene kan, etter mitt syn, kun forstås ut fra tanken om den profesjonelle lærer som makter å velge arbeidsmåter som passer innenfor den virkelighet der faget skal settes ut i livet. Denne motsetningen skyldes at juristene i prosessen overvåket formuleringene for å sikre at alle kompetansemålene kunne brukes i møte med alle elevgrupper i hele Norge uten å stå i fare for å krenke noen. Rommet for variasjon i arbeidsmåter er derfor sannsynligvis større enn kompetansemålene avspeiler innenfor de fleste lokalsamfunn i Norge. Det er elevgrunnlaget og konteksten for undervisningen som bestemmer hva det er rimelig og rett å gjøre. I en del klasser og skoler vil det være nødvendig å differensiere arbeidsmåtene for å ivareta elevenes ulike hjemmebakgrunn. Kompetansemålene har fått ganske åpne formuleringer for å unngå å dirigere arbeidsformene i faget. Planen forsøker ikke å være didaktisk kreativ og er ingen metodisk veiledning.

Mot slutten av læreplanprosessen ble det drøftet hvorvidt samtale om var et tilstrekkelig målbart kompetansemål til å inngå i læreplaner innenfor Kunnskapsløftet. Begrepet er beholdt fordi muntlighet står så sterkt i faget, og muntlig prøveform er den endelige evalueringsformen. Muntlig ferdighet inngår som en viktig del av faget gjennom hele skoleløpet.

De grunnleggende ferdighetene å kunne uttrykke seg muntlig, lese, skrive, regne og bruke digitale hjelpemidler omtales spesifikt i læreplanen. De politiske føringer i KRL slutter ikke med planen, da det også er utviklet en offisiell veiledning, jfr. KRL-boka 2005, 21-42. Veiledningen hevder behovet for å holde sammen forståelsen av ferdighetene som både mål og middel slik: "De grunnleggende ferdighetene kan både bidra til utvikling av fagkompetanse og være en del av fagkompetansen i det enkelte fag” (Utdanningsdirektoratet, 2005, 24). Faget har videre fătt hjelp til implementeringen ved at det er opprettet et eget nettsted, http://www.krlnett.no/. Her foreligger mange ressurser i form av fagartikler, metodiske artikler og hele Kildesamlingen er frigitt i digital form (Rasmussen \& Thomassen, 1999).

\section{Fagspesifikke ferdigheter?}

Fagplangruppa resonnerte mye fram og tilbake når det gjaldt behovet for å formulere fagspesifikke ferdigheter. Den eneste fagspesifikke ferdigheten som er inkludert i planen er evnen til å føre etiske resonnement, det vil si evnen til å vurdere etisk. Fagplangruppa hadde ønske om å innarbeide evne til å vise omsorg som en fagspesifikk ferdighet for å unngå en ensidig vekt på intellektuelle ferdigheter. Tanken var at denne ferdigheten kunne tilordnes taksonomisk utvikling ved å få et videre og videre virkeområde: i gruppa, på 
trinnet, i skolegården, i familien, i nærmiljøet, i lokalsamfunnet osv i retning av det globale samfunn. Dette møtte bastant motstand fra juridisk hold. Argumentet var at skolen ikke kunne inkludere kompetansemål som skulle oppfylles utenfor skolens område. Det ville ikke kunne måles. Etter vårt syn stod dette synspunktet i motsetning til læringsplakatens punkt 4, 10 og 11 som forutsetter at hjem og lokalsamfunn er involvert i opplæringen. Læringsplakaten er overordnet fagplanen.

En kan videre spørre: Hvorfor fem ferdigheter og ikke seks eller sju, og hvorfor akkurat disse fem? Hvorfor er ikke evne til samarbeid en ferdighet, eller evne til etisk refleksjon eller evne til samarbeid og omsorg ansett som nødvendige ferdigheter for morgendagens samfunn? Etter regjeringsskiftet høsten 2005 ble det da også en endring etter at de viktigste elementene i Kunnskapsløftet i form av læreplanene var vedtatt 18. august 2005, og da også etter at KRL-planen var satt ut i livet. Da Øystein Djupedal ble minister i Kunnskapsdepartementet, tok han en viss omkamp om dette med grunnleggende ferdigheter. Han kunne ikke enkelt gå inn og endre alle læreplanene for fag, men valgte å få utvidet forståelsen av basiskompetanse gjennom å legge inn en del II i læreplanverket kalt Prinsipper og rammer for opplcringen. Dette begrunner han i en artikkel/tale fra 29. november 2005 ved å henvise til premissdokumentene for Kunnskapsløftet, St. meld. Nr. 30 (2003/2004) Kultur for læring, på denne måten:

Regjeringen mener det er behov for å gi elevene en bredere basiskompetanse og stille tydeligere krav til grunnleggende ferdigheter - dette i tråd med det regjeringspartiene gikk inn for i Stortingets innstilling til Kultur for læring. Basiskompetanse er:

Ferdigheter i lesing, skriving, regneferdigheter og tallforståelse. Ferdigheter i engelsk. Digital kompetanse. Læringsstrategier og motivasjon. Sosial kompetanse.

Dette vil kreve endringer. Men min oppfatning er at dersom alle disse kompetansene skulle inkluderes i læreplanene for det enkelte fag, vil dette kunne føre til at målene blir utydelige og overlessede.

(...)

I Del II blir det fastsatt hvordan arbeid med læringsstrategier, motivasjon til elevene og utviklingen av sosial kompetanse skal integreres i opplæringen. (Djupedal, 2005)

Slik har den nye regjeringen med henvisning til den reformens grunnlagsdokumenter, gjort forsøk på å korrigere det den oppfattet som et snevert kunnskapssyn. Den begrunnet et bredere kunnskapssyn slik:

Regjeringen legger et bredt kunnskapssyn til grunn. Kunnskap er ferdigheter, fakta, forskning, men kunnskap er også mye mer:

- Kunnskap er dannelse; kritisk tenkning, analytiske evner og refleksjon

- Kunnskap er kompetanse til å arbeide sammen med andre mot felles mål, evne til demokratisk og solidarisk deltakelse 
- Og, ikke minst, kunnskap er evnen til å stadig kunne tilegne seg ny (ibid) kunnskap gjennom å møte og mestre nye utfordringer hele livet

Dette synet har fått konkret utslag i form av en nyskrevet del (del II som følger etter generell del), en kortfattet tekst kalt Prinsipper for opplceringen $i$ Kunnskapsløftet (Utdanningsdirektoratet, 2006). Teksten har gyldighet for alle fag og nivåer og får således også tilbakevirkende kraft på det igangsatte KRL-faget. Læringsplakaten har fått henvisninger både til Opplæringsloven og læreplanverkets generelle del til hvert av de 11 punktene. Deretter kommer sju nye avsnitt under overskriftene: "Sosial og kulturell kompetanse, Motivasjon for læring og læringsstrategier, Elevmedvirkning, Tilpasset opplæring og likeverdige muligheter, Læreres og instruktørers kompetanse og rolle, Samarbeid med hjemmet og Samarbeid med lokalsamfunnet.” For KRL er flere av punktene interessante. Det første avsnittet om Sosial og kulturell kompetanse følger opp intensjonene fra kunnskapsministerens tale om at kunnskap er dannelse: "Et tydelig verdigrunnlag og en bred kulturforståelse er grunnleggende for et inkluderende sosial fellesskap (...).” Deretter kan vi lese følgende overordnede føring:

Opplæringen skal bidra til utvikling av sosial tilhørighet og mestring av ulike roller i samfunns- og arbeidsliv og i fritiden. For å utvikle elevenes kulturelle kompetanse for deltakelse i et multikulturelt samfunn, skal opplæringen legge til rett for at elevene får kunnskaper om ulike kulturer og erfaring med et bredt spekter av kulturelle uttrykksformer.

Hele del II understreker behovet for bred danning, den enkeltes behov for å lære i egen takt og mulighet til å påvirke læringens innhold, læring i sosiale fellesskap og behovet for aktiv samfunnsdeltakelse. Den vekt formal danning og utvikling av iboende evner får gjennom denne teksten veier opp for det Myhre (1994) kalte metodeformalisme, det som en altfor ensidig bruk av grunnleggende ferdigheter kan føre til. Djupedal rydder her plass for mer allmenndanning og demper dermed inntrykket av at læring i reformen skal ha kortsiktig nytteverdi. Innenfor KRL-faglig utdanning vil man merke seg siste setningen om behov for "kunnskaper om ulike kulturer og erfaring med et bredt spekter av kulturelle uttrykksformer.” Dette gir KRL-faget en sentral plass i grunnskolen, og her avløses stram juridisk tenkning av pedagogisk relevant språkbruk. Læring involverer erfaring, erfaringer som også kan involvere deltakelse i samfunnet utenfor skolen, slik jeg ser det. Det ser dermed også ut til at den nye del II i prinsippene for Kunnskapsløftet kan gi rom for mer fagspesifikke ferdigheter i KRL slik at faget kan bidra solid til den ønskede sosiale og kulturelle kompetansen. 


\section{Oppsummering}

Artikkelen har drøftet møtet mellom fag og politikk i en læreplanprosess eksemplifisert med grunnskolefaget KRL. Det er særlig forholdet mellom ideologisk og formell læreplan som har vært i fokus. Det er ført en todelt diskusjon, én i forlengelse av FN-uttalelsen fra 2004 med fornyet aktualitet etter EMD-dommen i juni 2007, og én i forlengelse av Kunnskapsløftets satsing på grunnleggende ferdigheter. Vi har sett at juridiske og pedagogiske betraktningsmåter kan komme i konflikt, og at lovverk og planverk kan komme i utakt med hverandre. Fagprofil, fagets formål og fritaksbestemmelsene i skolen har vært gjenstand for drøfting. Vi har sett at i noen spørsmål har de politiske føringene vært styrende og i andre spørsmål har faglige argumenter fått gjennomslag.

Klafkis teori om kategorial dannelse advarer mot en forståelse av grunnleggende ferdigheter som enten mål eller middel. Et både og er nødvendig Vi drøftet behovet for mer fagspesifikke ferdigheter. Et kritisk blikk på Kunnskapsløftet kan hentes fra reformens grunnlagsdokument, St.meld. 30 Tid for læring, der en ikke bare opererer med "grunnleggende ferdigheter", men med "basiskompetanse” og også begrepsparet "allmenndannelse og basiskompetanse."

En dialektikk mellom ferdigheter og faginnhold synes nødvendig, men da på en slik måte at faget danner utgangspunkt for valg av arbeidsformer. Det nye avsnittet om Prinsipper for opplæringen i Kunnskapsløftet gir rom for større vektlegging av fagspesifikke ferdigheter i KRL, særlig begrunnet i omtalen av Sosial og kulturell kompetanse, Elevmedvirkning og Samarbeid med lokalmiljøet. I veiledningen til KRL-faget er dette uttrykt slik: "I KRLfaget vil det også være av særlig betydning å utvikle evnen til sosialt samspill og dialog, og til å vise verdibaserte holdninger, etisk vurderingsevne og moralsk skjønn” (Utdanningsdirektoratet, 2005, 29).

\section{Litteratur:}

Askeland, N., \& Maagerø, E. (2007). Kunnskapsløftet og grunnleggende ferdigheter. Kompendium fra lcerere i Rygge, Råde og Våler kommuner. Lastet ned fra http://www-

lu.hive.no/videreutdanning/vrr/documents/kompedium_vrr_050607_red.pdf

Breistein, I. F., \& Beckmann, H. B. (2006). Minkende bruk av sang og musikk i KRL. Lastet ned 30.07, 2007 fra http://ansgarskolen.ekanal.no/sider/tekst.asp?side=473

Clemet, K. (2004). Derfor trenger vi nye lcereplaner. Lastet ned 30.07, 2007 fra http://mondosearch.skolenettet.no/cgi-bin/MsmGo.exe? grab_id=0\&page_id=41363\&query $=21.09 .2004 \&$ hiword $=21.09 .2004 \% 20$

Djupedal, Ø. (2005). Hva skjer nå med læereplanene i Kunnskapsløftet? Lastet ned 30.07, 2007 fra

http://www.regjeringen.no/nb/dep/kd/dep/Kunnskapsminister_Oystein_Kare_Djupedal_taler_artikler/2005/Hvaskjer-med-lareplanene-i-Kunnskapsloftet.html?id=113209

Engen, T. O. (1997). Det nye kristendoms- og livssynsfaget sett fra en 
minoritetspedagogisk synsvinkel. Prismet, 48(6), 243-250.

European Court of Human Rights. (2007). Case of Folgerø and others v Norway

(Application no. 15472/02). Lastet ned 15.09, 2007 fra

http://cmiskp.echr.coe.int////tkp197/viewhbkm.asp?

action=open\&table=F69A27FD8FB86142BF01C1166DEA398649\&key=63211\&sessionld=2174745\&skin=hudocen\&attachment=true

Evenshaug, O. r., \& Hallen, D. (1977). Barne- og ungdomspsykologi (2. utg.). Oslo: Fabritius.

FNs menneskerettskomite. (2004). CCPR/C/82/DR/D/1155/2003. Lastet ned 14.09, 2007 fra

http://www.regjeringen.no/upload/kilde/ufd/prm/2004/0049/ddd/pdfv/237023norsk_fn_mr-kom_om_krl-faget.pdf

Goodlad, J. I. (Ed.). (1979). Curriculum inquiry: the study of curriculum practice. New York: McGraw-Hill.

Gravem, P. (2004). KRL-et fag for alle? KRL-faget som svar på utfordringer i en flerkulturell enhetsskole. Vallset: Oplandske Bokforlag.

Keast, J. (Ed.). (2007). Religious diversity and intercultural education: a reference book for schools. Strasbourg: Council of Europe.

Klafki, W. (2001). Dannelsesteori og didaktik: nye studier (B. Christensen, Trans.). Århus: Klim.

KUF. (1987). Mønsterplan for grunnskolen: M 87. Oslo: Aschehoug : Kirke- og undervisningsdepartementet.

Kuyk, E., Jensen, R., Lankshear, D., Manna, E. L., \& Schreiner, P. (Eds.). (2007). Religious Education in Europe : Situation and current trends in schools. Oslo: IKO Publishing House.

Myhre, R. (1978). Innføring i pedagogikk 2: Skole- og undervisningsteori (2. utg. ed.). Oslo: Fabritius.

Myhre, R. (1994). Oppdragelse i helhetspedagogisk perspektiv. Oslo: Ad notam Gyldendal.

OECD. (2003). Summary of the final report "Key Competencies for a Successful Life and a Well-Functioning Society". Lastet ned 12.05, 2006 fra http://www.portalstat.admin.ch/deseco/deseco_finalreport_summary.pdf

OECD. (2005). The Definition and Selection of Key Compenecies : Executive Summary. Lastet ned 12.05, 2006 fra https://www.pisa.oecd.org/dataoecd/47/61/35070367.pdf

Rasmussen, T., \& Thomassen, E. (Eds.). (1999). Kildesamling : til kristendomskunnskap med religions- og livssynsorientering. Oslo: Nasjonalt læremiddelsenter.

Skolenettet. (2004). Læreplangrupper for grunnskolen og gjennomgående fag. Lastet ned 28.07, 2007 fra http://skolenettet.no/upload/11953/laereplandeltakere_pulje1_20050420.pdf

UFD/Læringssenteret. (2002). KRL-boka: Kristendoms-, religions- og livssynskunnskap : Læreplan for den 10-årige grunnskolen : Lcreplanveiledning : Rundskriv om KRLfaget og begrenset fritak : Informasjon til foreldre og skjema for delvis fritak (No. 82486-0945-6). Oslo: Læringssenteret.

Utdannings- og forskningsdepartementet. (2004). St.meld. nr 30 (2003-2004) Kultur for lering. Oslo: UFD.

Utdanningsdirektoratet. (2005). KRL-boka 2005: Kristendoms-, religions- og livssynskunnskap, lcereplan for 1.-10. årstrinn, lcereplanveiledning og informasjon, from http://www.krlnett.no/innhold/krkbok/lareplan.pdf

Utdanningsdirektoratet. (2006). Prinsipper for opplceringen i Kunnskapsløftet. Lastet ned 30.07, 2007 fra http://www.udir.no/templates/udir/TM_Artikkel.aspx? id=2112\&utskrift $=1$

Østberg, S. (1998). Religionshistorie og religionsdidaktikk. I: S. Hjelde \& I. M. Ruud (Eds.), Enhet i mangfold? : 100 år med religionshistorie i Norge (s. 239-261). Oslo: Tano Aschehoug. 